
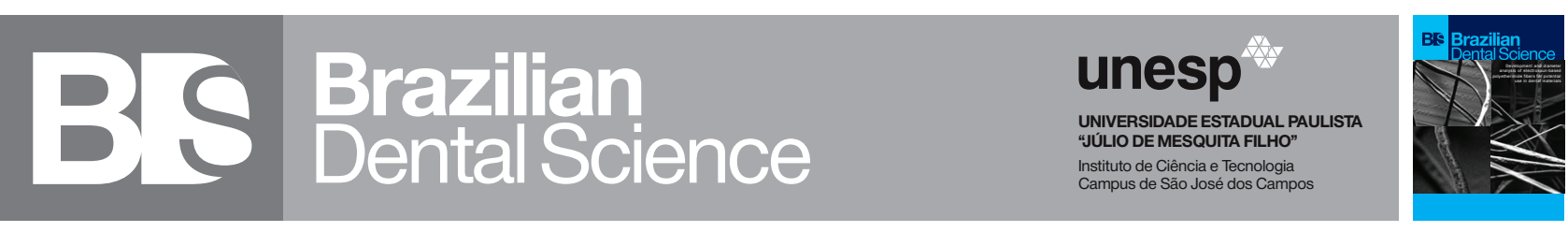

\title{
Knowledge Level of Iranian Dental Practitioners Towards Digital Radiography And Cone-Beam Computed Tomography
}

Nível de conhecimento de dentistas Iranianos sobre Radiografia Digital e Tomografia Computadorizada de Feixe Cônico

Fatemeh SALEMI ${ }^{1}$, Abbas SHOKRI ${ }^{1}$, Maryam FOROOZANDEH ${ }^{1}$, Maryam FARHADIAN $^{2}$, Ayoub YEGANEH $^{1}$
1 - Department of Oral and Maxillofacial Radiology, Dental School, Hamadan University of Medical Sciences, Hamadan, Iran.
2 - Department of Epidemiology, School of Public Health, Hamadan University of Medical Sciences, Hamadan, Iran.

\section{ABSTRACT}

Objective: TThis study aimed to assess the knowledge level of Iranian dental practitioners about digital radiography(DR)andcone-beamcomputed tomography (CBCT). Material and Methods: In this crosssectional study, a researcher-designed questionnaire was administered among 180 general dentists and specialists. The questionnaire had three main domains of demographic information, fifteen questions about knowledge of DR (advantages, disadvantages, physical properties) and twenty six questions about knowledge of CBCT (indications, applications, advantages, route of knowledge acquisition). Data were analyzed using descriptive statistics, t-test and Pearson's correlation coefficient. Results: Of 180 participants, 76 (42.2\%) were females. The minimum, maximum and mean \pm standard deviation scores obtained in DR were 4, 14 , and $9.031 \pm 1.85$ and in CBCT were 0,26 and $18.56 \pm 4.81$, respectively. In the CBCT domain, the participants had maximum knowledge about "low radiation dose" $(72.8 \%)$ and minimum knowledge about the "role of CBCT in determination of bone density" (45\%). In DR domain, the participants had maximum knowledge about "no need for radiographic films" (75.6\%) and minimum knowledge about "not requiring manual processing" (15.6\%). Overall, participants had higher level of knowledge about CBCT than DR. An inverse correlation was noted between age and work experience with the number of correct answers. However, no significant difference was noted in the knowledge level of males and females regarding CBCT or DR ( $p=0.233$ and $p=0.227$, respectively). Conclusions: further education seem imperative for dentists in this respect for more efficient diagnosis and treatment planning, minimize patient radiation dose and save time and cost.

\section{KEYWORDS}

Digital radiography; Cone-Beam computed tomography; Knowledge; Dentists.

\section{RESUMO}

Objetivos: Avaliar o nível de conhecimento de dentistas iranianos sobre radiografia digital (RD) e tomografia computadorizada de feixe cônico (TCFC). Materiais e métodos: Neste estudo transversal, um questionário, elaborado por pesquisadores, foi aplicado a 180 dentistas clínicos geral e especialistas. O questionário tinha três domínios principais de informação demográfica, quinze questões sobre conhecimento de $\mathrm{RD}$ (vantagens, desvantagens, propriedades físicas) e vinte e seis questões sobre conhecimento de CBCT (indicações, aplicações, vantagens, protocolo de aquisição). Os dados foram analisados por meio de estatística descritiva, teste t e coeficiente de correlação de Pearson. Resultados: Dos 180 participantes, $76(42,2 \%)$ eram do sexo feminino. Os escores mínimo, máximo e média \pm desvio padrão obtidos na $\mathrm{RD}$ foram 4, 14 e 9,031 $\pm 1,85$ e na CBCT foram 0,26 e 18,56 $\pm 4,81$, respectivamente. No domínio CBCT, os participantes tinham conhecimento máximo sobre "baixa dose de radiação" (72,8\%) e conhecimento mínimo sobre o "papel da CBCT na determinação da densidade óssea" (45\%). No domínio RD, os participantes possuíam conhecimento máximo sobre "não há necessidade de filmes radiográficos" $(75,6 \%)$ e conhecimento mínimo sobre "não requer processamento manual" $(15,6 \%)$. No geral, os participantes tinham maior nível de conhecimento sobre CBCT do que RD. Foi observado correlação inversa entre idade e experiência de trabalho com o número de acertos. No entanto, nenhuma diferença significativa foi observada no nível de conhecimento de homens e mulheres sobre TCFC ou RD ( $p=0,233$ e $p=$ 0,227 respectivamente). Conclusão: Parece imperativo para os dentistas iranianos, mais educação nesse aspecto para diagnóstico e planejamento de tratamento mais eficientes, minimizar a dose de radiação para paciente, economizar tempo e custos.

\section{PALAVRAS-CHAVE}

Cirurgião-dentista; Conhecimento; Radiografia digital; Tomografia computadorizada de feixe cônico. 


\section{INTRODUCTION}

$\mathrm{T} \mathrm{n}$ the past century, conventional $\perp$ radiography was the only available image acquisition tool in medicine and dentistry. In the recent years, conventional radiography is being replaced with digital radiography both in dental schools and in private offices. Digital radiography has advantages over conventional radiography such as shorter exposure time, lower patient radiation dose, and elimination of the film processing steps, fast image acquisition and processing, easy image transfer through the Internet and better instruction of patients [1,2].

Since the introduction of digital radiography, many advances have been made in information technology that led to gradual replacement of conventional or analog radiography with digital radiography $[3,4]$. However, despite the advances in digital technology, many dentists still prefer to use the conventional radiography probably due to the fact that digital radiography requires costly equipment such as digital sensors. $[1,2]$ On the other hand, analog radiography has long been used by dental practitioners as an efficient diagnostic tool, and its replacement with digital radiography require education and training of dentists and enhancing their knowledge about the advantages and disadvantages of this modality [4].

Use of cone-beam computed tomography (CBCT) enhances diagnosis in a wide range of dental procedures. CBCT has a lower cost than conventional computed tomography (CT). It occupies less space, has a shorter scanning time and lower patient radiation dose. It also enables interactive analyses and multiplanar reconstruction of images $[2,4]$. The common applications of CBCT in dentistry include evaluation of implant site, assessment of dentofacial structures for orthodontic treatment, evaluation of temporomandibular joints, localization of impacted teeth, evaluation of the position of third molars relative to the mandibular canal, and evaluation of pathological conditions (infection, cysts and tumors) involving the jaw and facial bones. [5] Interpretation of CBCT images by dental practitioners requires a basic level of experience and skills. Thus, unexperienced dentists may have significant errors in interpretation of CBCT images, resulting in a high percentage of misdiagnoses or false positive results. The European Academy of Dentomaxillofacial Radiology has set guidelines for this purpose for the European countries while such guidelines are not available in many other countries [6].

In the recent years, CBCT has been suggested as an accurate imaging modality for many dental procedures, and related courses have been added to the undergraduate and postgraduate dental curricula. Moreover, continuing education courses on this topic are held for dental practitioners graduated prior to addition of these courses to dental curricula. However, it should be noted that standard educational courses on CBCT are not available for all dentists. In order to achieve a satisfactory level of CBCT knowledge, it is required to provide necessary training in various forms, such as holding workshops and seminars [7].

Despite the increasing use and availability of these imaging modalities, the knowledge level of dental practitioners about these imaging modalities has not been extensively evaluated. Thus, this study aimed to assess the knowledge level of Iranian dental practitioners regarding digital radiography and CBCT.

\section{MATERIAL AND METHODS}

This study was approved by the ethics committee of Hamadan University of 
Medical Sciences (IR.UMSHA.REC.1396.73). In this cross-sectional study, a researcherdesigned questionnaire according to previous studies was used [8-10]. this questionnaire included three main domains of demographic information (age, gender, general or specialty practice, type of specialty, work experience), knowledge about digital radiography (advantages, disadvantages, physical properties), and knowledge about CBCT (indications, applications, advantages, route of knowledge acquisition). Nine questions were multiple choice and 18 questions were dichotomous yes/no questions.

After initial designing of the questionnaire, its validity and reliability were evaluated and confirmed. For this purpose, the opinions of 10 experts were asked regarding the conformity of the content of the measurement tool with the study objectives, both qualitatively and quantitatively. In qualitative assessment of the content, experts were requested to provide feedbacks regarding the measurement tool, and the questionnaire was revised accordingly. For quantitative assessment of the content, the content validity ratio (CVR) and the content validity index (CVI) were calculated. CVI was calculated by summing the positive scores for the items that were considered "relevant, but requiring revision" and "completely relevant" divided by the total number of experts. To determine the CVR, the experts were requested to assess and score each item using a three-point scale of "necessary", "useful" and "not necessary". Also, test-retest reliability method was used to confirm the reliability of the questionnaire.

The inclusion criterion was all dentists (general and specialists) attending the School of Dentistry of Hamadan University of Medical Sciences and working in offices and dental clinics of Hamadan city. The exclusion criterion was unwillingness for participation in the study.

The questionnaire was administered among 180 dental practitioners and they were requested to fill it out. They were also informed that they had no obligation to answer the questions and the results would be used for educational purposes in dental community.

After data collection, the knowledge score of the participants was calculated. Data were analyzed using SPSS version 21 via the descriptive statistics, t-test and Pearson's correlation coefficient. $\mathrm{p}<0.05$ was considered significant.

\section{Questionnaire}

This questionnaire aims to assess the level of knowledge of dentists about digital radiography and CBCT. Thank you for taking the time to fill out this questionnaire. Please note that there is no obligation to answer the questions. 


\section{Demographic questions}

Gender:

Age:

general dentist or specialist:

Field of specialty:

Graduation year:

Work experience:

Please mark the reason(s) of using digital radiological techniques?

Decrease the patient radiation dose: Yes No

Higher spatial resolution than that of analog radiography: Yes No

Contribute to treatment planning: Yes No

Creation and archiving of electronic patient files and tele-radiology: Yes No

Requires less equipment than conventional radiography: Yes No

Decreases the consumption of radiographic films: Yes No

No image artefact: Yes No

Eliminates the need for manual film processing: Yes No

Larger dimensions of photostimulable phosphor plate (PSP): Yes No

Mechanical trauma causes artifacts on PSP sensors: Yes No

Immediate availability of image after exposure in CCD sensor: Yes No

High cost of replacement is the drawbacks of CCD sensors: Yes No

Analog radiography is still the best and cheapest imaging modalities available: Yes No

Better visualized on a negatoscope than on a display monitor: Yes No

Printing with a higher resolution would increase the final resolution of images: Yes No

Please mark the reason(s) of using CBCT techniques?

A beneficial diagnostic tool in dentistry: Yes No

A useful modality for 3D assessment: Yes No

Assessment of Implant site: Yes No

Assessment of teeth and jaws for orthodontic treatment: Yes No

Evaluation of simple jaw traumas: Yes No

Evaluation of presence of cysts/tumors: Yes No

Localization of impacted teeth: Yes No

Evaluation of temporomandibular joints: Yes No 
Evaluation of root canal morphology: Yes No

Identifying root resorption areas: Yes No

Evaluation of root fracture: Yes No

Evaluation of the position of third molars relative to the mandibular canal: Yes No

Evaluation of soft tissue lesions: Yes No

Determination of bone density: Yes No

\section{What is the difference between CT and CBCT?}

CBCT has lower patient radiation dose than CT: Yes No

CBCT occupies less space: Yes No

CBCT is more expensive than CT: Yes No

The scanning time of CBCT is longer than that of CT: Yes No

CBCT image reconstruction can be performed by personal computers: Yes No

CBCT has less reconstruction ability than CT: Yes No

CBCT has higher applications than CT for soft tissue assessment: Yes No

Cephalometric images can be reconstructed using CBCT data: Yes No

Reconstructed cephalometry has lower quality than conventional radiography:Yes No

Education courses are required to acquire new information about CBCT? Yes No

\section{Which of the followings is true about CBCT indications?}

Indicate when conventional techniques cannot provide adequate information: Yes No

CBCT can be requested without clinical examination: Yes No

CBCT can be routinely requested for treatment planning: Yes No

\section{How do you update your knowledge about CBCT?}

Congress Continuing education Books Journals Internet 


\section{RESULTS}

Of 180 participants, 76 (42.2\%) were females and 100 (55.6\%) were males; 4 individuals did not report their gender. The minimum age of participants was 23 years and the maximum age was 57 years, with a mean age of 35.08 years.

Minimum and maximum work experience of participants was 1 year and 36 years, respectively with a mean of 10.37 years.

Of all, 117 (65\%) were general dentists, $54(30 \%)$ were specialists and $9(5 \%)$ did not mention whether they were general dentists or specialists. The minimum, maximum and mean \pm standard deviation scores obtained in digital radiography were 4,14 , and $9.031 \pm 1.85$ and in CBCT were 0,26 and $18.56 \pm 4.81$, respectively.

Table I - Frequency of responses to knowledge questions about digital radiography

\begin{tabular}{|c|c|c|c|}
\hline Question topic & $\begin{array}{l}\text { Number and } \\
\text { percentage } \\
\text { of correct } \\
\text { answers }\end{array}$ & $\begin{array}{l}\text { Number and } \\
\text { percentage of } \\
\text { wrong an- } \\
\text { swers }\end{array}$ & $\begin{array}{l}\text { Number and } \\
\text { percentage of } \\
\text { unanswered } \\
\text { questions }\end{array}$ \\
\hline $\begin{array}{l}\text { Reduction of patient } \\
\text { radiation dose }\end{array}$ & $60(33.3 \%)$ & $116(64.4 \%)$ & $4(2.2 \%)$ \\
\hline Image resolution & $38(21.1 \%)$ & $139(72.2 \%)$ & $3(1.7 \%)$ \\
\hline $\begin{array}{l}\text { Aid in treatment } \\
\text { planning }\end{array}$ & $138(76.7 \%)$ & $39(21.7 \%)$ & $3(1.7 \%)$ \\
\hline Tele-radiography & $123(68.3 \%)$ & $55(30.6 \%)$ & $2(1.1 \%)$ \\
\hline Less equipment & $170(94.4 \%)$ & $7(3.9 \%)$ & $3(1.7 \%)$ \\
\hline $\begin{array}{l}\text { Decreased } \\
\text { radiographic film } \\
\text { consumption }\end{array}$ & $136(75.6 \%)$ & $42(23.3 \%)$ & $2(1.1 \%)$ \\
\hline No image artifacts & $126(70 \%)$ & $49(27.2 \%)$ & $5(2.8 \%)$ \\
\hline $\begin{array}{l}\text { Not requiring manual } \\
\text { processing }\end{array}$ & $28(15.6 \%)$ & $148(82.2 \%)$ & $4(2.2 \%)$ \\
\hline $\begin{array}{l}\text { PSP sensor dimen- } \\
\text { sions }\end{array}$ & $89(49.4 \%)$ & $84(46.7 \%)$ & $7(3.9 \%)$ \\
\hline PSP damage & $158(87.8 \%)$ & $12(6.7 \%)$ & $10(5.6 \%)$ \\
\hline $\begin{array}{c}\text { Main characteristic } \\
\text { of CCD }\end{array}$ & $156(86.7 \%)$ & $12(6.7 \%)$ & $10(5.6 \%)$ \\
\hline Drawbacks of CCD & $164(91.1 \%)$ & $10(5.6 \%)$ & $6(3.3 \%)$ \\
\hline $\begin{array}{l}\text { Superiority of analog } \\
\text { radiography }\end{array}$ & $140(77.8 \%)$ & $33(18.3 \%)$ & $7(3.9 \%)$ \\
\hline $\begin{array}{l}\text { Radiographic } \\
\text { negatoscope or } \\
\text { monitor }\end{array}$ & $57(34.7 \%)$ & $118(56.6 \%)$ & $5(2.8 \%)$ \\
\hline $\begin{array}{l}\text { Printing with a higher } \\
\text { resolution printer }\end{array}$ & $100(55.5 \%)$ & 76 (42.2\%) & $4(2.2 \%)$ \\
\hline
\end{tabular}

Table II - Frequency of responses to knowledge questions about CBCT

\begin{tabular}{|c|c|c|c|}
\hline Question topic & $\begin{array}{l}\text { Number and } \\
\text { percentage } \\
\text { of correct } \\
\text { answers }\end{array}$ & $\begin{array}{l}\text { Number and } \\
\text { percentage of } \\
\text { wrong an- } \\
\text { swers }\end{array}$ & $\begin{array}{l}\text { Number and } \\
\text { percentage of } \\
\text { unanswered } \\
\text { questions }\end{array}$ \\
\hline $\begin{array}{l}\text { CBCT is a beneficial } \\
\text { diagnostic tool }\end{array}$ & $167(92.8 \%)$ & $5(2.8 \%)$ & $8(4.4 \%)$ \\
\hline $\begin{array}{l}\text { Need for 3D asses- } \\
\text { sment }\end{array}$ & $16(88.9 \%)$ & $9(5 \%)$ & $11(6.1 \%)$ \\
\hline $\begin{array}{l}\text { Implant treatment } \\
\text { planning }\end{array}$ & 171(95\%) & $2(1.1 \%)$ & $7(3.9 \%)$ \\
\hline Orthodontic treatment & $59(32.8 \%)$ & $110(61.1 \%)$ & $11(6.1 \%)$ \\
\hline Simple jaw trauma & $141(78.3 \%)$ & $25(13.9 \%)$ & $14(7.8 \%)$ \\
\hline $\begin{array}{l}\text { Assessment of cysts/ } \\
\text { tumors }\end{array}$ & $142(78.9 \%)$ & $29(16.1 \%)$ & $9(5 \%)$ \\
\hline $\begin{array}{l}\text { Position of impacted } \\
\text { teeth }\end{array}$ & $126(70 \%)$ & $44(24.4 \%)$ & $10(5.6 \%)$ \\
\hline $\begin{array}{l}\text { Temporomandibular } \\
\text { joints }\end{array}$ & $115(63.9 \%)$ & $56(31.1 \%)$ & $9(5 \%)$ \\
\hline Root canal morphology & $89(49.4 \%)$ & $81(45 \%)$ & $10(5.6 \%)$ \\
\hline $\begin{array}{l}\text { Finding resorption } \\
\text { areas }\end{array}$ & $94(52.2 \%)$ & $75(41.7 \%)$ & $11(6.1 \%)$ \\
\hline $\begin{array}{l}\text { Evaluation of root } \\
\text { fracture }\end{array}$ & $104(57.8 \%)$ & $64(35.6 \%)$ & $12(6.7 \%)$ \\
\hline $\begin{array}{l}\text { Evaluation of third } \\
\text { molar position }\end{array}$ & $155(86.1 \%)$ & $18(10 \%)$ & $7(3.9 \%)$ \\
\hline $\begin{array}{l}\text { Soft tissue assess- } \\
\text { ment }\end{array}$ & $120(66.7 \%)$ & $49(27.2 \%)$ & $11(6.1 \%)$ \\
\hline $\begin{array}{l}\text { Determination of bone } \\
\text { density }\end{array}$ & $47(26.1 \%)$ & $125(69.4 \%)$ & $8(4.4 \%)$ \\
\hline Radiation dose & $144(80 \%)$ & $27(15 \%)$ & $9(5 \%)$ \\
\hline $\begin{array}{l}\text { Occupying smaller } \\
\text { space }\end{array}$ & $131(72.8 \%)$ & $30(16.7 \%)$ & $19(10.6 \%)$ \\
\hline More expensive & $85(47.1 \%)$ & $81(45 \%)$ & $14(7.8 \%)$ \\
\hline Scanning time & $114(63.3 \%)$ & $51(28.3 \%)$ & $15(8.3 \%)$ \\
\hline $\begin{array}{l}\text { Reconstruction with } \\
\text { personal computer }\end{array}$ & $152(84.4 \%)$ & $15(8.3 \%)$ & $13(7.2 \%)$ \\
\hline $\begin{array}{l}\text { Less reconstruction } \\
\text { abilities }\end{array}$ & $113(62.8 \%)$ & $42(23.3 \%)$ & $25(13.9 \%)$ \\
\hline $\begin{array}{l}\text { Soft tissue assess- } \\
\text { ment }\end{array}$ & $97(52.9 \%)$ & $67(37.2 \%)$ & $16(8.9 \%)$ \\
\hline $\begin{array}{l}\text { Cephalometric image } \\
\text { reconstruction }\end{array}$ & $145(80.6 \%)$ & $20(11.1 \%)$ & $15(8.3 \%)$ \\
\hline $\begin{array}{l}\text { Quality of reconstruc- } \\
\text { ted cephalometric } \\
\text { image }\end{array}$ & $103(57.2 \%)$ & $50(27.8 \%)$ & $27(15 \%)$ \\
\hline $\begin{array}{l}\text { Need for continuing } \\
\text { education }\end{array}$ & $136(75.6 \%)$ & $36(20 \%)$ & $8(4.4 \%)$ \\
\hline Indication & $153(58 \%)$ & $19(10.6 \%)$ & $8(4.4 \%)$ \\
\hline $\begin{array}{l}\text { Without clinical exa- } \\
\text { mination }\end{array}$ & $159(88.3 \%)$ & $11(6.1 \%)$ & $10(5.6 \%)$ \\
\hline Routine prescription & $136(75.6 \%)$ & $35(19.4 \%)$ & $9(5 \%)$ \\
\hline
\end{tabular}


The number of correct answers was 9.031 \pm 1.85 in the digital radiography (Table I) and $18.56 \pm 4.81$ in the CBCT domain (Table II). The number of correct answers in the digital radiography domain was $9.51 \pm 1.69$ in females and $9.17 \pm 1.77$ in males $(\mathrm{p}=0.227)$. Number of correct answers in the CBCT domain was $19.21 \pm 4.82$ in females and $18.38 \pm 4.48$ in males $(\mathrm{p}=0.233)$. Also, t-test showed no significant difference in the mean number of correct responses in digital radiography and CBCT domains between males and females.

The Pearson's correlation coefficient between age and work experience with digital awareness scores were respectively, $r=0.308$ (p $=0.002)$ and $r=0.144(p=0.12)$. The Pearson's correlation coefficient between age and work experience with CBCT awareness scores were respectively, $r=0.153(p=0.133)$ and $r=0.036$ $(\mathrm{p}=0.698)$.

The results showed an inverse correlation between age and work experience with the number of correct answers. In other words, by an increase in age (and work experience), the knowledge level about digital radiography and CBCT decreased.

The results of t-test showed a significant difference in the mean number of correct answers to digital radiography and CBCT questions between general dentists and specialists. Regarding the level of knowledge about digital radiography, the mean number of correct answers was $9.88 \pm 1.7$ for specialists and $9.08 \pm 1.86$ for general dentists $(p=0.009)$. Regarding the level of knowledge about CBCT, the mean number of correct answers was $17.76 \pm 4.75$ for general dentists and $20.79 \pm 3.72$ for specialists ( $<<0.001$ ). The ways to get information about CBCT and the level of interest in using them are summarized in Table III.
Table III - Frequency of responses to the question in CBCT domain regarding methods to enhance knowledge about $\mathrm{CBCT}$

\begin{tabular}{|c|c|c|c|c|}
\hline $\begin{array}{l}\text { Question } \\
\text { number }\end{array}$ & $\begin{array}{l}\text { Answer } \\
\text { choices }\end{array}$ & $\begin{array}{l}\text { Number and } \\
\text { percentage of } \\
\text { Yes answers }\end{array}$ & $\begin{array}{l}\text { Number and } \\
\text { percentage of } \\
\text { No answers }\end{array}$ & $\begin{array}{l}\text { Number and } \\
\text { percentage of } \\
\text { unanswered } \\
\text { questions }\end{array}$ \\
\hline 1 & Congress & $53(29.4 \%)$ & $125(69.4 \%)$ & $2(11 \%)$ \\
\hline 2 & $\begin{array}{l}\text { Continuing } \\
\text { education }\end{array}$ & $55(30.6 \%)$ & $124(68.9 \%)$ & $1(0.6 \%)$ \\
\hline 3 & Book & $36(20 \%)$ & $143(79.4 \%)$ & $1(0.6 \%)$ \\
\hline 4 & Journal & $19(10.6 \%)$ & $160(88.9 \%)$ & $1(0.6 \%)$ \\
\hline 5 & Internet & $52(28.9 \%)$ & $127(70.6 \%)$ & $1(0.6 \%)$ \\
\hline
\end{tabular}

\section{DISCUSSION}

CBCT has advantages compared with $\mathrm{CT}$, the most important of which, is the lower patient radiation dose and high resolution (less than a millimeter). [11] According to our results, participants had maximum knowledge about the advantages of CBCT with regard to image reconstruction in a personal computer, cephalometric image reconstruction and lower patient radiation dose while the participants had minimum knowledge about the assessment of bone density using CBCT.

In a study by Kamburoğlu et al. [12] participants had higher knowledge about dose reduction and easier processing while the participants had minimum knowledge about the space occupied by the CBCT system, and its lower cost. In a study by Gecgelen et al. [10] orthodontists had maximum knowledge about the advantages of CBCT over CT including its lower patient radiation dose and shorter scanning time. If dental practitioners have adequate knowledge about the advantages of CBCT, and given that CT and CBCT both provide similar diagnostic information, the imaging modality with lower patient radiation dose would be preferred.

In our study, the indications of CBCT that were most commonly agreed upon were preoperative evaluation for implant placement, assessment of the position of third molars, and 
3D evaluations while the participants had the lowest level of knowledge about the indications of CBCT for orthodontic treatment planning, morphological assessment of root canals and evaluation of root resorption. Ghoncheh et al. [13] reported that $72.2 \%$ of the dentists used the CBCT technique to evaluate the location of implants, whereas $19.7 \%, 3.2 \%$, and $2.7 \%$ of the subjects applied it to localize the inferior alveolar nerve (IAN), evaluate the location of implants and localize the IAN, and perform cephalometric analysis, respectively. Mahdizadeh et al. reported that the main indications of CBCT included implant placement, assessment of cysts and tumors, and trauma cases while CBCT was least commonly prescribed for periodontal disease and caries. Shetty et al. [14] reported that CBCT was most commonly prescribed for implant treatment, evaluation of impacted teeth and assessment of cysts and tumors. At present, CBCT is the most commonly requested imaging modality for implant assessment [15] and also CBCT provides detailed information about impacted teeth. [16] This statement was also confirmed in our study.

In digital radiography domain, patients acquired the maximum knowledge score regarding the advantages of digital radiography including lower patient radiation dose than filmbased radiography, aid in treatment planning and tele-radiography. According to Yalcinkaya et al. [8] the most common reasons for using digital radiography were knowledge about its lower dose than the conventional film-based radiography, being fast and easy to use, and not requiring manual processing. However, a large number of dental practitioners still believed that this modality is costly and were not willing to use it due to the lack of equipment and unfamiliarity with the computerized steps of digital radiography. In another study, dental practitioners preferred digital radiography to conventional radiography due to its lower patient radiation dose, the ability to change the contrast and brightness for better visualization of image and the ability to save electronic images. The most common reason for not using it was the high cost of equipment [17].

In our study, $49.4 \%$ of participants had adequate knowledge about the size of PSP sensors compared with the radiographic films, and $87.8 \%$ knew that damage to PSP sensors would cause image artifacts. Also, $86.7 \%$ knew that CCD images would be available immediately after exposure and $91.1 \%$ were aware of the sensitivity of CCD sensors and high cost of their replacement. In the study by Yalcinkaya et al, [8] the level of knowledge about the advantages of digital radiography was moderate $(50.91 \%)$ while the level of knowledge about its disadvantages was little (47.2\%). The level of knowledge about the advantages and disadvantages of CCD was little (respectively $50.9 \%$ and $52.8 \%$ ).

In our study, participants had higher level of knowledge about CBCT than digital radiography. However, no significant difference existed in the knowledge level of males and females regarding the two imaging modalities.

Gijbels et al. [19] reported that male dental practitioners had higher knowledge level and tendency to use digital radiography. However, similar to our study, Yalcinkaya et al. [8] showed no significant correlation between the knowledge level of endodontists and gender.

Our study revealed an inverse correlation between age and work experience with the frequency of correct answers. In other words, the level of knowledge of participants about digital radiography and CBCT decreased with aging. Esmaeili et al. [1] found a significant correlation between the knowledge level about digital radiography and age and work experience such that the level of knowledge decreased by an increase in age and work experience of participants. Similar to our findings, Giray et al. [8] reported that Young pediatric dentists (years of experience 1-9) had significantly higher knowledge of CBCT than older professionals (10 years or more of experience). On the other hand, 
academic individuals and $\mathrm{PhD}$ students had the highest information about CBCT. The knowledge level of individuals decreases by aging and distancing from the academic environments. Participants who work in an academic environment often have higher knowledge about CBCT because they can easier interact with radiologists in the academic environment. Older dental practitioners generally tend to ignore technological advances. High cost of equipment is probably another reason for not using the novel imaging modalities [17].

In this study, participants reported that they mainly acquired knowledge about the radiographic modalities through continuing education programs, congresses and Internet. In the study by Balabaskaran et al. [20] participants reported that they mainly gained knowledge through lectures, educational courses and Internet. In the study by Gecgelen et al. [10] participants acquired knowledge through seminars. In their study, many participants stated that they had graduated prior to the advent of CBCT. They suggested that CBCT practical courses should be included in dental curricula.

One reason for lower rate of participation of dental practitioners in seminars and congresses is the long commute between their city of residence from the capital and larger cities where most congresses are held. Thus, holding educational programs in small cities can also increase the knowledge level of dental practitioners practicing in these areas [17]. Also, educational programs should be provided in the form of seminars, continuing education courses, congresses and online courses; the latter is reportedly the most efficient route of instruction. [10,20] Future studies are required to assess the knowledge level of dental practitioners about other imaging modalities such as CT and magnetic resonance imaging.

In this study, the number of participating dentists was high. Also the questions in the questionnaire had validity and reliability and sufficient number. But one limitation of this study was that it was better to evaluate the dentists' information in two stages, one before training and one after.

\section{CONCLUSION}

Considering the inadequate knowledge level of dentists about the advantages and disadvantages of imaging modalities, further education and training in the form of continuing education programs, seem imperative for dentists in this respect for more efficient diagnosis and treatment planning ,minimize patient radiation dose and save time and cost.

\section{Acknowledgement}

This study was approved by the ethics committee of Hamadan University of Medical Sciences, in the No.9606214008. The authors would like to thank the research deputy of this university and school of dentistry for their support.

\section{REFERENCES}

1. Esmaei li F, Shoja P,Zarandi A. The knowledge of general dentists in Tabriz aboutusing of digital radiography in dentistry. Merit Res J Med Med Sci. 2016;4(5):255-9.

2. Ray S, Misra D, Dhawan A, Tyagi K, Prabhat M, Khatri M. Knowledge, awareness, and aptitude of general dentists toward dental radiology and CBCT: A questionnaire study. JIAOMR. 2018,30(2):110-5. doi: 10.4103/jiaomr. jiaomr 11517.

3. Hasan A, Khan JA, Ali B, Afshan Z, Shakir MN, Shah SYA. Practices of dentists about digital techniquesin dental radiology and radiographic safety. JPak Dent Assoc 2019;28(4):181-6.

4. Rovaris K, de Faria Vasconcelos K, do Nascimento EH, Oliveira ML, Freitas $\mathrm{DQ}$, Haiter-Neto F. Brazilian young dental practitioners' use and acceptance of digital radiographic examinations. Imaging Sci Dent. 2016;46(4):239-44.

5. Bhagat BA, Nagrik AP, Yemle SB. Dental practitioners' awareness, knowledge and attitude towards cone beam computed tomography. IOSRJ. 2016;15(3):33-7.

6. Horner K, Islam M, Flygare L, Tsiklakis K, Whaites E. Basic principles for use of dental cone beam computed tomography: consensus guidelines of the European Academy of Dental and Maxillofacial Radiology. Dentomaxillofac Radiol. 2009; 38(4):187-95. 
7. Johari M, MoudiE Dental students' and residents' knowledge and attitudes towards application of cone-beam computed tomography in Babol University of Medical Sciences, Babol, Iran. J MASH DENT SCH. 2020;44(2):174-83

8. Yalcinkaya SE, Berker YG, Peker S, Basturk FB. Knowledge and attitudes of Turkish endodontists towards digital radiology and cone beam computed tomography. Niger J Clin Pract. 2014;17(4):471-8.

9. QirreshE, Rabi H, Rabi T. Current status of awareness, knowledge and attitude of dentists in Palestine towards cone beam computed tomography: a survey. Oral Biol Dent. 2016;4(1):1-4.

10. Gecgelen M, Yilmaz A, Ozer T. Knowledge and attitudes towards digital radiography and CBCT among orthodontists. Biomed Res. 2016;27(3):95964.

11. Nikoyan L, Patel R. Intraoral scanner, three-dimensional imaging, and three-dimensional printing in the dental office. Dent Clin North Am. 2020;64(2):365-78.

12. Kamburoğlu K, Kurşun S, Akarslan Z. Dental students' knowledge and attitudes towards cone beam computed tomography in Turkey. Dentomaxillofac Radiol. 2011; 40(7):439-43.

13. Ghoncheh Z, Paninoush M, Kaviani H, Kharazifard MJ, Zahirnia F. Knowledge and attitude of Iranian dentists towards cone beam computed tomography. Front Dent. 2019;16(5):379-85.
14. Shetty SR, Castelino RL, Babu SG, Prasanna, Rangare A, Laxmana Knowledge and attitude of dentists towards cone beam computed tomography in mangalore - a questionnaire survey. Austin J Radiol. 2015;2(2):1016-21.

15. Guberina N, Dietrich U, Arweiler-Harbeck D, Forsting M, Ringelstein A. Comparison of radiation doses imparted during 128-, 256-,384-multislice CT-scanners and cone beam computed tomography for intra-and perioperative cochlear implant assessment. Am J Otolaryngol. 2017; 38(6):649-53.

16. Miresmaeili A, Neilsen IL, Varshosaz M, Farhadian N, Mollabashi V, Moghymbeigi A, et al. Web-based evaluation of experts' opinions on impacted maxillary canines forced eruption using CBCT. Dental Press J Orthod. 2015;20(2):90-9.

17. Dölekoğlu S, Fişekçioğlu E, illgüy M, ilgüy D. The usage of digital radiography and cone beam computed tomography among Turkish dentists. Dentomaxillofac Radiol. 2011;40(6):379-84.

18. Giray FE, Peker S, Yalcinkaya SE, Kargul B, Aps J. Attitudes and knowledge of paediatric dentists' on digital radiography and cone beam computed tomography. J Pak Med Assoc. 2019; 69(2):205-210.

19. Gijbels F, Debaveye D, Vanderstappen M, Jacobs R. Digital radiographic equipment in the Belgian dental office. Radiat Prot Dosimetry. 2005;117(13):309-12.

20. Balabaskaran K. Awareness and attitude among dental professional towards CBCT. IOSR J Dent Med Sci. 2013;10(5):55-9.

\section{Maryam Foroozandeh}

\section{(Corresponding address)}

Department of Oral \& Maxillofacial Radiology, Dental School, Hamadan University of Medical Sciences, Hamadan, Iran.

Email: drforoozandeh1991@yahoo.com

Date submitted: 2020 Aug 17 Accept submission: 2020 Sep 11 